Article

\title{
Soil Organic Carbon Storage and Stability in the Aspen-Conifer Ecotone in Montane Forests in Utah, USA
}

\section{Mercedes Román Dobarco * and Helga Van Miegroet}

Department of Wildland Resources and Ecology Center, Utah State University, Logan, UT 84322-5230, USA; E-Mail: helga.vanmiegroet@usu.edu

* Author to whom correspondence should be addressed; E-Mail: mercetadzio@gmail.com; Tel.: +1-435-574-8329; Fax: +1-435-797-3796.

Received: 24 January 2014; in revised form: 21 March 2014 / Accepted: 26 March 2014 /

Published: 8 April 2014

\begin{abstract}
To assess the potential impact of conifer encroachment on soil organic carbon (SOC) dynamics and storage in montane aspen-conifer forests from the interior western US, we sampled mineral soils $(0-15 \mathrm{~cm})$ across the aspen-conifer ecotones in southern and northern Utah and quantified total SOC stocks, stable SOC (i.e., mineral-associated SOC (MoM)), labile SOC (i.e., light fraction (LF), decomposable $\left(\mathrm{CO}_{2}\right.$ release during long-term aerobic incubations) and soluble SOC (hot water extractable organic carbon (HWEOC)). Total SOC storage (47.0 $\pm 16.5 \mathrm{Mg} \mathrm{C}^{-1}$ ) and labile SOC as $\mathrm{LF}\left(14.0 \pm 7.10 \mathrm{Mg} \mathrm{C} \mathrm{ha}{ }^{-1}\right)$, SOC decomposability (cumulative released $\mathrm{CO}_{2}-\mathrm{C}$ of $5.6 \pm 3.8 \mathrm{~g} \mathrm{C} \mathrm{g}^{-1}$ soil $)$ or HWEOC $\left(0.6 \pm 0.6 \mathrm{mg} \mathrm{C} \mathrm{g}^{-1}\right.$ soil $)$ did not differ substantially with vegetation type, although a slight increase in HWEOC was observed with increasing conifer in the overstory. There were statistically significant differences $(p=0.035)$ in stable MoM storage, which was higher under aspen $\left(31.2 \pm 15.1 \mathrm{Mg} \mathrm{C}^{-1}\right)$ than under conifer $\left(22.8 \pm 9.0 \mathrm{Mg} \mathrm{C} \mathrm{ha}^{-1}\right)$, with intermediate values under mixed $\left(25.7 \pm 8.8 \mathrm{Mg} \mathrm{Cha}^{-1}\right)$. Texture had the greatest impact on SOC distribution among labile and stable fractions, with increasing stabilization in MoM and decreasing bio-availability of SOC with increasing silt + clay content. Only at lower silt + clay contents $(40 \%-70 \%)$ could we discern the influence of vegetation on MoM content. This highlights the importance of chemical protection mechanisms for long-term $\mathrm{C}$ sequestration.
\end{abstract}

Keywords: Populus tremuloides; conifer encroachment; soil organic carbon; SOC stabilization; mineral-associated SOC; SOC decomposability; mixed aspen-conifer forests 


\begin{abstract}
Abbreviations
CM; Cedar Mountain; DBH; diameter at breast height; FB; Franklin Basin; HWEOC; hot water extractable organic carbon; IC; inorganic carbon; LBA; live basal area; LME; linear mixed effects; LF; light fraction; MA > $53 \mu \mathrm{m}$; mineral-associated soil organic carbon in the sand fraction; MoM; mineral-associated soil organic carbon in the silt and clay fraction; SD; standard deviation; SOC; soil organic carbon; SUVA; specific ultra violet absorbance at $254 \mathrm{~nm}$; TOC; total organic carbon; TC; total carbon.
\end{abstract}

\title{
1. Introduction
}

Efforts to optimize $\mathrm{C}$ sequestration in forest ecosystems have mainly focused on enhancing stand biomass productivity and density by adapting rotation length, thinning intensity and tree species composition. Less attention is often paid to the effect of forest management and changes in species composition on soil organic carbon (SOC) storage and dynamics. Soils store two thirds of total C in terrestrial ecosystems [1], which is equivalent to $1400-1500 \mathrm{Pg} \mathrm{C}$ in the first meter [2,3]. Even small changes in SOC storage or dynamics, whether induced by anthropogenic or natural factors, can alter the ecosystem $\mathrm{C}$ balance [4], with significant impact on atmospheric $\mathrm{CO}_{2}$ levels at the regional scale.

SOC storage at the landscape scale is determined by the interaction of climate, soil properties, vegetation, relief, land use history, disturbance regime and the chemical composition of soil organic matter [5]. The balance between $\mathrm{C}$ input, primarily as litter or rhizodeposition, and $\mathrm{C}$ output via soil respiration determines whether forest soils are $\mathrm{C}$ sources or sinks [6,7]. For particular site conditions (e.g., soil properties, aspect, climate, etc.), forest species composition and stand development determine the amount, allocation (aboveground and belowground) and chemistry of organic matter inputs [6,8-10]. Soil environmental conditions (e.g., temperature, water and $\mathrm{O}_{2}$ availability, $\mathrm{pH}$ ), the abundance and type of microbes and the chemical composition of organic matter, in turn, regulate SOC decomposition rates [11]. Biochemical recalcitrance (i.e., resistance to microbial decomposition due to intrinsic molecular make-up) has greater control over decomposition rates in the litter layer. In the mineral soil, the persistence of SOC is further enhanced by the mineral matrix through additional protection mechanisms, such as the isolation of organic matter inside aggregates (i.e., physical protection) and surface interactions between organic compounds and mineral particles, mainly from the silt and clay fraction (i.e., chemical protection) [12]. The interaction of these protection mechanisms and soil microclimate creates a continuum of SOC pools with different chemical composition and residence time [13,14] that differs among forest species [7,15].

Quaking aspen (Populus tremuloides Michx.) is an iconic species of the Intermountain West, USA. Aspen is typically a seral species, eventually replaced by more shade-tolerant species, like Douglas fir (Pseudotsuga menziesii (Mirbel) Franco) at lower elevations or subalpine fir (Abies lasiocarpa (Hook.) Nutt.) and Engelmann spruce (Picea engelmannii Parry ex Engelm.) at higher elevations [16]. As a pioneer species, aspen regeneration frequently depends on small or coarse-scale disturbances, like fires or landslides [17]. However, aspen is ecologically versatile and has multiple modes of regeneration and stand development [17,18]. Aspen can form stable, uneven aged stands that regenerate continuously or through gap-phase regeneration [17] and is also found in coexistence with conifers in 
mixed stands for several decades or centuries [17,18]. Decline in aspen extent in the Intermountain West (so-called sudden aspen decline or SAD) has been attributed to natural succession coupled with fire suppression, ungulate grazing and climate change [19-23].

Aspen and conifer stands from semi-arid montane and subalpine forests differ considerably in soil microclimate [24-27], hydrology [24], litter quality [27,28], soil chemistry [27,29], soil microbial community structure [27] and SOC content and dynamics [25-27]. Woldeselassie et al. [26] found that montane aspen stands in northern Utah had higher SOC stock $\left(96.2 \pm 26.7 \mathrm{Mg} \mathrm{C} \mathrm{ha}^{-1}\right)$ than adjacent conifer stands $\left(66.9 \pm 18.6 \mathrm{Mg} \mathrm{C}^{-1}\right)$ in the top $60 \mathrm{~cm}$ of mineral soil. SOC under aspen was also more persistent than SOC from conifer soils and had a higher proportion of mineral-associated SOC $(55 \% \pm 13 \%$ in aspen $v s .41 \% \pm 13 \%$ in conifers $)[25,26]$. A shift towards mixed and conifer-dominated stands could thus modify SOC dynamics and potentially reduce long-term SOC storage (i.e., SOC sequestration potential).

Several studies have addressed the properties of SOC under mixed aspen-conifer stands in the boreal climate $[15,30]$, but studies of SOC storage and stability in mixed stands in semi-arid climates are largely missing. In particular, we do not know whether changes in SOC properties occur gradually or abruptly at critical composition thresholds. It is also possible that mixed aspen-conifer stands have distinct SOC dynamics and, thus, represent an alternate state. The objective of this study was to assess the influence of forest composition on SOC storage and SOC stabilization in the mineral soil at the aspen-conifer ecotone in montane forests of Utah. The underlying hypotheses were: (1) SOC storage will decrease from aspen to conifer dominated stands; (2) with increasing conifer encroachment, a greater proportion will be stored as labile SOC; and (3) the proportion and quantity of protected SOC will conversely decrease with conifer encroachment. Understanding the processes controlling SOC storage and stabilization along the aspen-conifer gradient will provide insight to forecast the fate of SOC with conifer encroachment or climate change-induced vegetation shifts and may also inform management decisions when focusing on $\mathrm{C}$ sequestration as an ecosystem service.

\section{Materials and Methods}

\subsection{Study Sites}

To test our hypotheses, we chose study sites from southern Utah (Cedar Mountain) and northern Utah (Franklin Basin), expanding the geographical scope of previous studies.

Cedar Mountain (CM) is a high elevation plateau (1800-3200 m) located within the Colorado Plateau region in southwestern Utah [31] (Figure 1). Mean annual precipitation is $812 \mathrm{~mm}$ [32], most of it as snow from October through April. Monsoonal storms are common in late summer [33]. The average monthly air temperature ranges from $-3.8^{\circ} \mathrm{C}$ in December to $15.5{ }^{\circ} \mathrm{C}$ in July [32]. Mountain grasslands consisting of Letterman needlegrass (Stipa lettermani Vasey) and Kentucky bluegrass (Poa pratensis L.) alternate with woodlands of quaking aspen as the predominant communities [34]. Subalpine fir, Douglas fir and white fir (Abies concolor (Gordon \& Glend.) Lindl. ex Hildebr.) appear scarcely in the landscape, mixed with aspen or forming small stands at the edges of the plateau. Patches of Gamble oak (Quercus gambelii Nutt.) occur in lower elevation areas [33]. 
Soil types are commonly Alfisols or Mollisols [31,35] developed mainly on sedimentary rock and igneous rock [36].

Figure 1. Aspen distribution in North America and the location of study areas.

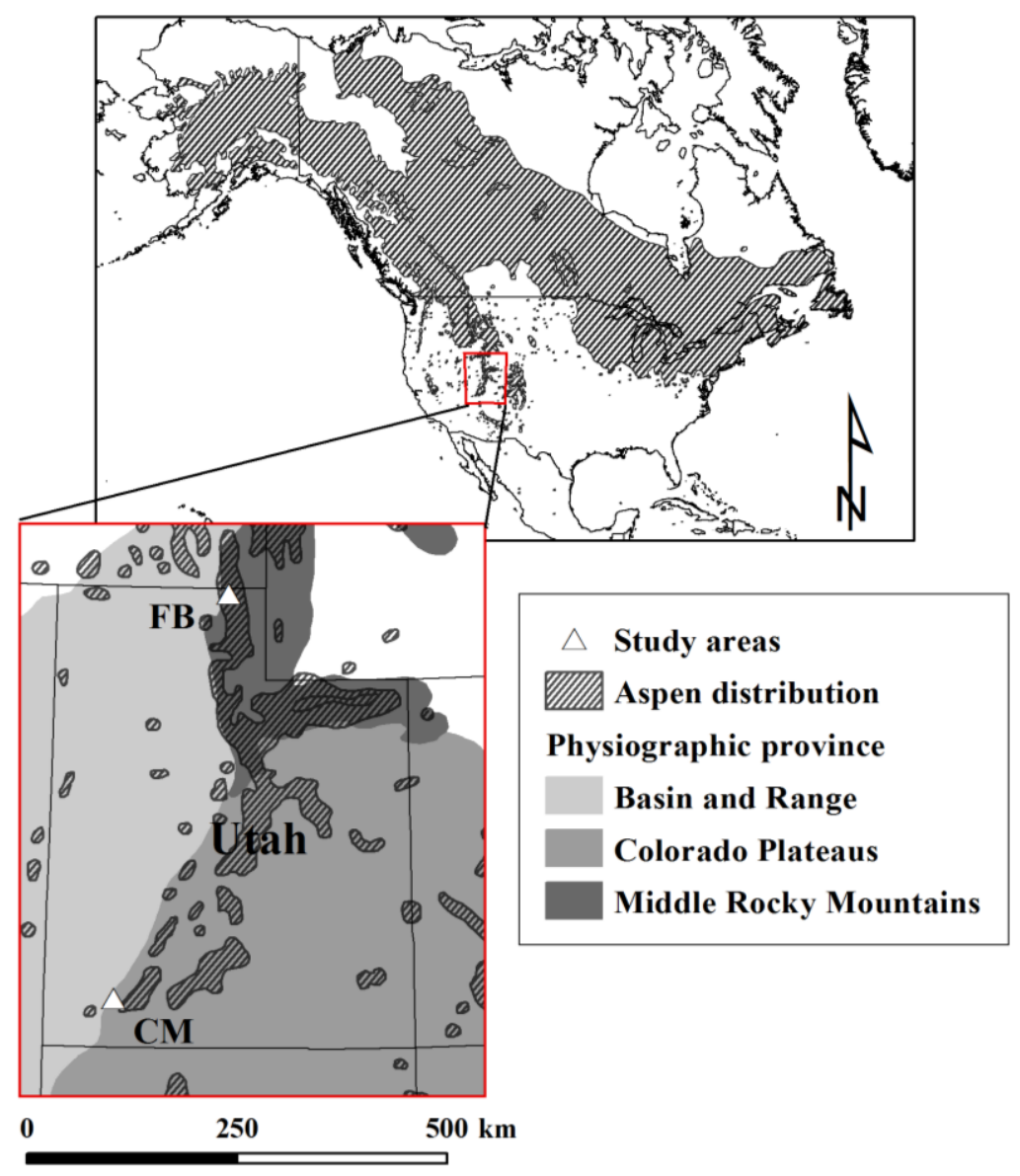

Franklin Basin (FB) is a montane-subalpine area (1770-3030 m) located between the Bear River Range and the Wasatch Range in the central Rocky Mountains, distributed between northeastern Utah and southeastern Idaho [37] (Figure 1). The precipitation regime is snow dominated, with a mean annual precipitation of $1197 \mathrm{~mm}$ [32]. The monthly average temperature ranges from $-6.9{ }^{\circ} \mathrm{C}$ in December to $16.4{ }^{\circ} \mathrm{C}$ in July [32]. Forest ecosystems are represented by quaking aspen and mixed conifer stands of Douglas fir, subalpine fir and limber pine (Pinus flexilis E. James). Non-forested areas are occupied by curl leaf mountain mahogany (Cercocarpus ledifolius Nutt. ex Torr. \& A. Gray) or mountain big sagebrush (Artemisia tridentata Nutt. ssp. vaseyana (Rydb.) Beetle) [36]. Soils are commonly Alfisols and Mollisols, developed on limestone or quartzite sandstone.

\subsection{Study Design and Field Sampling}

This study used two sampling designs to characterize the influence of the overstory on SOC properties at different spatial scales. In the first design, the influence of a single tree or a small tree cluster on soil properties was evaluated [38,39]. The second design used plots of a $10-\mathrm{m}$ radius as sampling units to characterize stand composition along the gradient from pure aspen stands to pure conifer stands. 
In October of 2011, four sites at CM and two sites at FB were sampled following the first design, hereafter referred to as "transects", with three transects per site (Table 1). Within each transect, two soil cores (5-cm diameter; $0-15-\mathrm{cm}$ depth) were taken in the mineral soil beneath aspen, mixed and conifer cover. The cores were divided by $5-\mathrm{cm}$ intervals at the field and stored separately. Slope, elevation and aspect were similar within each transect. Pure conifer clusters were absent in one site at CM (CM1), while samples from one transect at another site (CM57) were excluded from the inventory, due to discrepancies in sampling and storage protocol. We did not describe soil pedons in our sites, but the characteristics of the topsoil were in agreement with those described in previous studies [26,37]. We generally observed a thin $\mathrm{O}$ horizon (i.e., superficial horizon dominated by organic matter, $>20 \%$ by weight of SOC) and a relatively deep A horizon (i.e., mineral topsoil with accumulation of organic matter, $<20 \%$ by weight of SOC) under aspen, whereas conifer soils had a thicker O horizon and a shallower and lighter A horizon.

Table 1. Topographic characteristics (mean \pm SD) and parent material of transects at Cedar Mountain (CM) and Franklin Basin (FB). Parent material not available (n.a.).

\begin{tabular}{lcccl}
\hline \multicolumn{1}{c}{ Site } & Elevation (m) & Slope (degrees) & Aspect & \multicolumn{1}{c}{ Parent Material } \\
\hline CM 1 & $2552 \pm 8$ & $14 \pm 9$ & N & Basalt \\
CM 2 & $2756 \pm 12$ & $24 \pm 12$ & N & Basic and intermediate igneous rock \\
CM 57 & $2773 \pm 11$ & $24 \pm 11$ & W & n.a. \\
CM 111 & $2685 \pm 9$ & $46 \pm 2$ & N & Limestone, sandstone and shale \\
FB 1 & $2098 \pm 9$ & $10 \pm 4$ & NE & Quartzite, sandstone and limestone \\
FB 2 & $2196 \pm 18$ & $15 \pm 5$ & E & Limestone \\
\hline
\end{tabular}

The second design, hereafter named "plots", was applied in CM the summers of 2011 and 2012. Potential sampling areas were identified a priori with the National Agricultural Imagery Program (NAIP) 1-m orthophoto (2009) and topographic maps using ArcGIS 9.3 (Esri, Redlands, CA., USA). Sampling areas were selected based on the existence of conifer, mixed and aspen patches of at least a 40-m diameter under similar slope, elevation and aspect conditions. Four to five plots of a 10-m radius were located at five different locations, for a total of 24 plots (Table 2). The minimum distance between adjacent plots was $30 \mathrm{~m}$, and the conditions of overstory composition and structure in the surrounding $10-\mathrm{m}$ buffer were homogenous to those within the plot to avoid edge effects. Five soil cores (5-cm diameter; $0-15-\mathrm{cm}$ depth) were randomly sampled within each plot and combined into one composite sample per plot. Two additional cores were collected and the 5-10 cm excised to calculate bulk density. Tree species, status (dead or alive) and diameter at breast height (DBH) (i.e., stem diameter at a $1.30-\mathrm{m}$ height) of all trees $>3 \mathrm{~cm}$ in diameter were recorded and used to calculate live basal area (LBA) by species $\left(\mathrm{m}^{2} \mathrm{ha}^{-1}\right)$ and live stem density $\left(\mathrm{n} \mathrm{ha}^{-1}\right)$. Overstory composition was classified by the percentage of live basal area occupied by aspen in three categories: aspen dominated ( $>75 \%$ LBA aspen), mixed (25\%-75\% LBA aspen) and conifer dominated ( $<25 \%$ LBA aspen). 
Table 2. Topographic and overstory characteristics of plots at Cedar Mountain. LBA, live basal area.

\begin{tabular}{|c|c|c|c|c|c|c|c|c|c|}
\hline \multirow{2}{*}{ Site } & \multirow{2}{*}{ Plot } & \multirow{2}{*}{ Elevation (m) } & \multirow{2}{*}{ Slope (degrees) } & \multirow{2}{*}{ Aspect } & \multicolumn{2}{|c|}{ Live Basal Area $\left(\mathrm{m}^{2} \mathrm{ha}^{-1}\right)$} & \multirow{2}{*}{ Contribution of Aspen to LBA (\%) } & \multicolumn{2}{|c|}{ Live Stem Density $\left(\mathrm{n} \mathrm{ha}^{-1}\right)$} \\
\hline & & & & & Aspen & Conifer & & Aspen & Conifer \\
\hline CM 5 & CM 5-1 & 2764 & 4 & $\mathrm{NE}$ & 28.9 & 6.1 & 82.5 & $1,055.6$ & 223.9 \\
\hline CM 5 & CM 5-2 & 2766 & 8 & $\mathrm{NE}$ & 0.0 & 67.0 & 0.0 & 0.0 & $2,499.4$ \\
\hline CM 5 & CM 5-3 & 2746 & 8 & $\mathrm{NE}$ & 35.5 & 17.5 & 66.9 & 649.2 & 519.4 \\
\hline CM 5 & CM 5-4 & 2759 & 9 & $\mathrm{NE}$ & 21.4 & 0.3 & 98.4 & 710.0 & 41.8 \\
\hline $\mathrm{CM} 8$ & CM 8-1 & 2651 & 19 & NW & 43.0 & 0.0 & 100.0 & $1,353.0$ & 0.0 \\
\hline $\mathrm{CM} 8$ & CM 8-2 & 2656 & 16 & $\mathrm{~N}$ & 8.8 & 50.1 & 15.0 & 241.1 & 551.2 \\
\hline $\mathrm{CM} 8$ & CM 8-3 & 2704 & 23 & NW & 56.9 & 37.3 & 60.4 & 563.5 & $1,390.0$ \\
\hline $\mathrm{CM} 8$ & CM 8-4 & 2700 & 26 & NW & 27.6 & 9.7 & 73.9 & 827.5 & 157.6 \\
\hline $\mathrm{CM} 8$ & CM 8-5 & 2685 & 26 & NW & 11.3 & 100.6 & 10.1 & 118.2 & 630.4 \\
\hline CM 15 & CM 15-1 & 2636 & 28 & $\mathrm{~W}$ & 57.0 & 36.6 & 60.9 & 641.1 & $1,518.5$ \\
\hline CM 15 & CM 15-2 & 2638 & 22 & $\mathrm{~W}$ & 0.0 & 47.4 & 0.0 & 0.0 & 914.2 \\
\hline CM 15 & CM 15-3 & 2688 & 20 & NW & 38.6 & 12.6 & 75.4 & 468.7 & 692.9 \\
\hline CM 15 & CM 15-4 & 2654 & 24 & $\mathrm{~W}$ & 28.0 & 4.1 & 87.1 & 634.7 & $1,025.2$ \\
\hline CM 15 & CM 15-5 & 2636 & 26 & $\mathrm{~W}$ & 27.0 & 6.7 & 80.0 & 305.9 & 183.5 \\
\hline CM 17 & CM 17-1 & 2725 & 4 & $\mathrm{~W}$ & 1.4 & 36.7 & 3.6 & 32.0 & $1,439.4$ \\
\hline CM 17 & CM 17-2 & 2738 & 4 & NW & 35.3 & 7.9 & 81.8 & $4,286.2$ & 287.9 \\
\hline CM 17 & CM 17-3 & 2725 & 7 & W & 21.8 & 1.2 & 94.6 & $1,615.5$ & 64.6 \\
\hline CM 17 & CM 17-4 & 2714 & 3 & $\mathrm{~W}$ & 13.1 & 6.7 & 66.3 & $1,340.6$ & 127.7 \\
\hline CM 17 & CM 17-5 & 2710 & 3 & $\mathrm{~W}$ & 0.9 & 16.6 & 5.3 & 223.4 & 861.8 \\
\hline CM 20 & CM 20-1 & 2883 & 4 & $\mathrm{~N}$ & 49.9 & 0.0 & 100.0 & $3,262.6$ & 0.0 \\
\hline CM 20 & CM 20-2 & 2901 & 3 & $\mathrm{~N}$ & 26.7 & 15.3 & 63.5 & 408.6 & 367.7 \\
\hline CM 20 & CM 20-3 & 2907 & 4 & $\mathrm{~N}$ & 27.5 & 46.0 & 37.4 & 383.8 & 639.7 \\
\hline CM 20 & CM 20-4 & 2903 & 4 & NW & 12.4 & 34.1 & 26.6 & 127.9 & 671.7 \\
\hline $\mathrm{CM} 20$ & CM 20-5 & 2895 & 5 & $\mathrm{~N}$ & 33.4 & 25.6 & 56.6 & 481.1 & 609.4 \\
\hline
\end{tabular}




\subsection{Laboratory Analyses}

Transects $(0-5 \mathrm{~cm})$ and plot composite samples $(0-15 \mathrm{~cm})$ were sieved $(2-\mathrm{mm}$ mesh) and stored at $4{ }^{\circ} \mathrm{C}$ to minimize microbial decomposition. Middle core sections $(5-10 \mathrm{~cm})$ from transects and plots were oven dried at $105{ }^{\circ} \mathrm{C}$ for $24 \mathrm{~h}$, sieved (2-mm mesh), weighed to determine bulk density and the percent of fine earth mass. Fine fraction samples were ground with a mortar and pestle and analyzed for total carbon (TC), inorganic carbon (IC) and total organic carbon (TOC) with a Skalar Primacs ${ }^{\text {SLC }}$ Analyzer (Skalar, Inc., Breda, The Netherlands). Average TOC concentration from the 5-10 cm, depth, bulk density and fine earth percentage were used to calculate SOC stocks $\left(\mathrm{Mg} \mathrm{C} \mathrm{ha}{ }^{-1}\right)$ for the first $15 \mathrm{~cm}$ of mineral soil. As bulk density increases with depth, while SOC concentration decreases, we considered the 5-10 cm section to represent the average properties of the entire $0-15 \mathrm{~cm}$ core. Soil texture analysis was performed with the pipette method [40] in transect $(0-5 \mathrm{~cm})$ and composite plot $(0-15 \mathrm{~cm})$ samples.

A multitude of fractionation methods have been developed with the purpose of dividing SOC into fractions with presumably different turnover rates [41,42]. In this study, we used a simplified size fractionation method: $20 \mathrm{~g}$ of air dried soil (0-15-cm depth for plot samples, $0-5-\mathrm{cm}$ depth for transect samples) were processed under the premise that free, large particulate organic matter and SOC associated with mineral particles of different sizes and mineralogy differ in the degree of stabilization and turnover time. The mineral-associated SOC in the clay and silt fraction (MoM) was separated by wet sieving through a $53-\mu \mathrm{m}$ sieve, with the $>53 \mu \mathrm{m}$ fraction further divided into a light fraction (LF) and mineral-associated SOC in the sand fraction (MA > 53) using electrostatic attraction, following a modification from Kaiser et al. [43]. The LF is generally composed of free and intra-aggregate particulate organic matter (i.e., relatively fresh organic matter, mainly of plant origin). MoM is considered to be more protected and to have a long residence, whereas SOC in the sand fraction is weakly bonded and has lower residence, but may also be partly composed of relatively recalcitrant charred material [41,44]. All fractions were ground with a mortar and pestle and analyzed for TC content with Skalar Primacs ${ }^{\text {SLC }}$ Analyzer (Skalar, Inc., Breda, The Netherlands), which constituted TOC, given that IC content was negligible in the bulk samples. The $\mathrm{C}$ recovery and relative contribution of each fraction to bulk SOC was calculated from the fractions' relative weights, TC concentrations and bulk soil TOC concentration. C recovery was on average $98.0 \% \pm 11.3 \%$, with five samples somewhat outside this range.

SOC decomposability (i.e., biologically available SOC) was determined with long-term (10 months) aerobic laboratory incubations of fresh soil samples $(0-5 \mathrm{~cm}$ transect, $0-15 \mathrm{~cm}$ plot $)$ following the protocol of Paul [45], as modified by Woldeselassie et al [26]. Cumulative $\mathrm{CO}_{2}-\mathrm{C}$ respired was expressed on a dry soil weight basis $\left(\mathrm{mg} \mathrm{CO}_{2}-\mathrm{C} \mathrm{g}\right.$ soil $\left.^{-1}\right)$ and normalized to $\mathrm{C}$ content (mg $\mathrm{CO}_{2}-\mathrm{C} \mathrm{g} \mathrm{C}^{-1}$ ) as an indicator of qualitative differences in SOC. Only plot samples collected in $2011(n=16)$ were incubated.

Hot water extractable organic carbon (HWEOC), considered by some authors as a good indicator of biologically available SOC $[46,47]$, was determined by mixing field-moist soils with distilled water in falcon tubes $(1: 10$ soil-water $(\mathrm{w} / \mathrm{v}))$ and heating the slurry in a hot bath at $85{ }^{\circ} \mathrm{C}$ for one hour. The solution was filtered through Whatman GF/F filters (pore size $\sim 0.7 \mu \mathrm{m}$ ) and the extractant analyzed for dissolved organic carbon (DOC) with a Phoenix 8000 Carbon Analyzer (Tekmar-Dohrmann, Mason, 
OH., USA). Specific ultraviolet absorbance at $254 \mathrm{~nm}$ (SUVA) of HWEOC, an estimate of DOC aromaticity which is used as an indicator of chemical recalcitrance [48], was measured with a Genesys 10 spectrophotometer (Thermo Scientific, Madison, WI., USA).

\subsection{Statistical Analyses}

Relationships between SOC properties were explored with Spearman's rank correlation coefficient using the R package, Hmisc, version 3.10-1.10 (R Foundation for Statistical Computing, Vienna, Austria) [49].

Linear mixed effects (LME) models were applied to test the effect of vegetation and soil texture on the SOC properties in both datasets. In the transect dataset, vegetation class (aspen, mixed and conifer) was treated as a categorical fixed effect and silt + clay content (\%) as a continuous fixed effect variable. The site and transect were considered random effect variables, with transect nested within site to account for the dependency among samples from the same transect and site. LME models applied to the plot dataset included overstory composition (aspen percent of LBA) and soil texture (silt + clay (\%)) as continuous fixed effect variables and site as a random effect variable.

LME models with vegetation class or overstory composition as explanatory variables were applied to sand (\%), silt (\%) and clay (\%) as response variables to ensure that potential differences in SOC properties across the vegetation gradient were not merely due to the occurrence of aspen and conifers in different soil conditions.

Data were transformed with the logarithm in base 10, the square root, the reciprocal transformation or the reciprocal square root when the assumptions of normality and homogeneity of variance were not met. Linear mixed models were applied with the R package, lmer, Test 2.0-3.0 [50]. Fixed effects were tested with Type III ANOVA, using Satterthwaite approximation for the degrees of freedom of the denominator for the $\mathrm{F}$ statistics. Bonferroni pairwise comparisons were used to test differences among estimated means when the main effect of vegetation class was statistically significant $(p<0.05)$. The estimated slope for silt + clay content in transect LME models was reported when the ANOVA test found it statistically significant, to inform on the magnitude and direction of the effect. Estimates for the intercept and slopes for overstory composition and silt + clay content were reported for all the plots LME models.

\section{Results and Discussion}

The plots at Cedar Mountain represented a broad gradient from pure aspen stands to conifer stands, with varying degrees of conifer encroachment and stand structure (Table 2). Across all plots, mean aspen LBA was $25.3 \pm 17.0 \mathrm{~m}^{2} \mathrm{ha}^{-1}$, a similar value to the $20.7 \pm 13.8 \mathrm{~m}^{2} \mathrm{ha}^{-1}$ reported by Rogers et al. [31] for stable aspen stands in Cedar Mountain. The mean conifer LBA (min-max) was $24.4(0-100.6) \mathrm{m}^{2} \mathrm{ha}^{-1}$. The average tree density (min-max) was $642(0-2499)$ live conifer ha ${ }^{-1}$ and $822(0-4286)$ live aspen $\mathrm{ha}^{-1}$, higher than the $315 \pm 201$ aspen stems $\mathrm{ha}^{-1}$ reported previously for this area [31]. The relative dead basal area was higher for aspen $(33.5 \% \pm 32.5 \%)$ than conifer $(5.5 \% \pm 10.6 \%)$ across all sampling sites. Nine plots had aspen dominated overstory (LBA aspen 21-50 $\mathrm{m}^{2} \mathrm{ha}^{-1}$ ), four of them showing signs of conifer encroachment; six plots had conifer dominated overstory (LBA conifer 17-101 $\mathrm{m}^{2} \mathrm{ha}^{-1}$ ); nine plots had mixed overstory (total 
LBA 20-94 $\mathrm{m}^{2} \mathrm{ha}^{-1}$ ). The distribution by diameter classes suggested that seven mixed plots may continue the succession towards conifer stands.

The SOC concentration in surface soils did not differ by vegetation class in the transect samples (Table 3), with an overall mean $( \pm \mathrm{SD})$ of $48.1 \pm 18.1 \mathrm{mg} \mathrm{C} \mathrm{g} \mathrm{soil}{ }^{-1}$. In the plots, SOC concentration ranged between 10.0 and $150 \mathrm{mg} \mathrm{C} \mathrm{g} \mathrm{soil}{ }^{-1}$, with a mean $( \pm \mathrm{SD})$ of $46.8 \pm 27.1 \mathrm{mg} \mathrm{C} \mathrm{g} \mathrm{soil}^{-1}$. The SOC content $\left(\mathrm{Mg} \mathrm{C} \mathrm{ha}^{-1}\right)$ in the transects was not statistically different among vegetation classes, with an overall mean $( \pm \mathrm{SD})$ of $47.2 \pm 16.8 \mathrm{Mg} \mathrm{Cha}^{-1}$, but followed the trend: aspen $>$ mixed $>$ conifer. The SOC content in the plots ranged between 14.4 and $80.9 \mathrm{Mg} \mathrm{C} \mathrm{ha}^{-1}$, with a mean ( \pm SD) of $46.8 \pm 16.2 \mathrm{Mg} \mathrm{C} \mathrm{ha}^{-1}$. SOC content did not follow any pattern nor did it change abruptly at a critical LBA threshold across the aspen-conifer gradient, but it varied across sampling sites (Figure 2 and Table 3). Our values for SOC content are comparable to those found by Woldeselassie et al. [26], who similarly did not find significant differences in SOC content in the top $15 \mathrm{~cm}$ of mineral soil between aspen $\left(49.5 \pm 7.9 \mathrm{Mg} \mathrm{Cha}^{-1}\right)$ and conifer stands $\left(54.9 \pm 20.3 \mathrm{Mg} \mathrm{C} \mathrm{ha}^{-1}\right)$ in montane forests from northern Utah.

Figure 2. SOC content $\left(\mathrm{mg} \mathrm{C} \mathrm{ha}^{-1}\right)(0-15 \mathrm{~cm})$ for the plots at Cedar Mountain (a) vs. aspen contribution to LBA (\%) and (b) by site. $\beta$ represents the slope for aspen LBA (\%).Statistically non-significant, n.s. The boxes represent the 25 and 75 percentiles. The median is represented by the horizontal bold line. The whiskers represent the 10th and 90th percentiles, and the circles correspond to outliers.
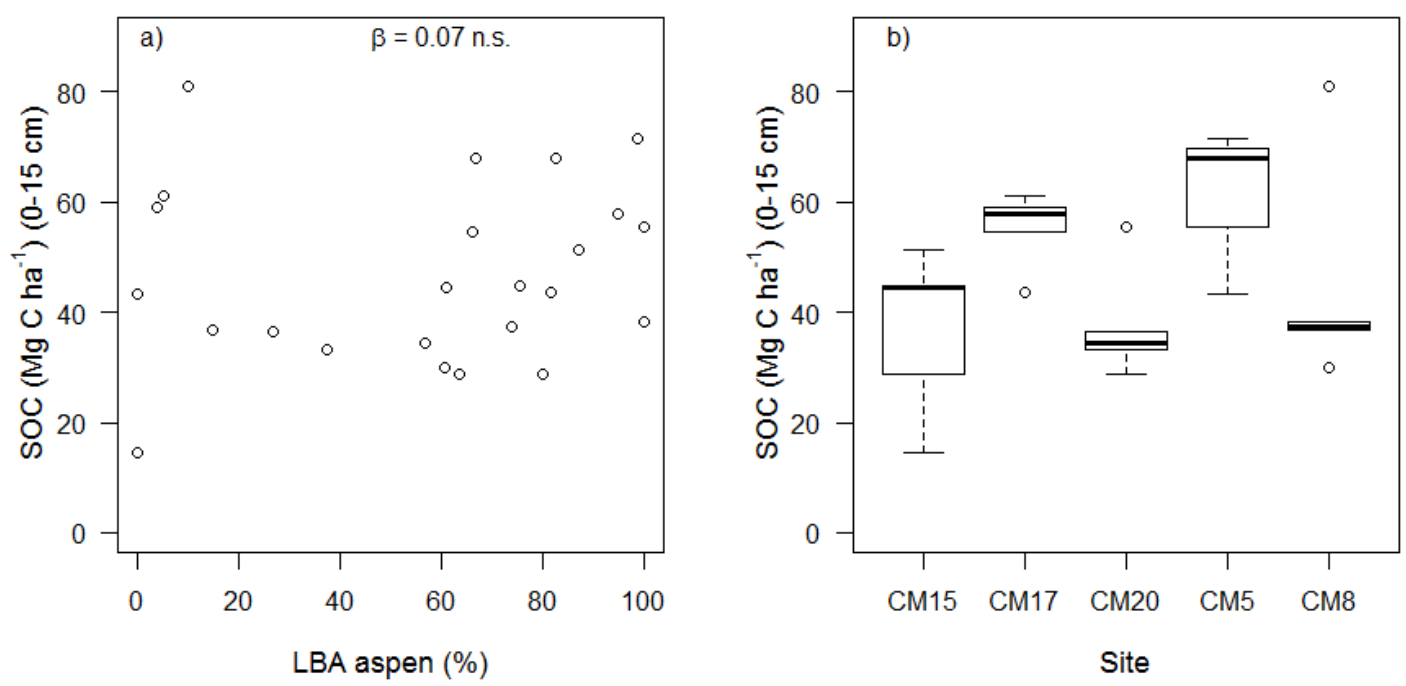

Although we did not find differences in SOC storage along the vegetation gradient, differences in distribution among labile and stable SOC fractions may be more relevant for $\mathrm{C}$ sequestration. Across all samples, over half of the SOC was stored in the more persistent MoM fraction (mean $\pm \mathrm{SD}: 56.1 \% \pm 12.7 \%$ for transects; $60.5 \% \pm 13.4 \%$ for plots), with around one-third stored as LF (mean \pm SD: $37.0 \% \pm 11.9 \%$ for transects; $30.4 \% \pm 10.3 \%$ for plots). Mineral-associated SOC in the sand fraction was a minor contributor, accounting for $<10 \%$ of total SOC (mean \pm SD: $6.9 \% \pm 3.3 \%$ for transects; $9.1 \% \pm 5.5 \%$ for plots) and, therefore, was not further considered in the statistical analyses. MoM content in the transect soils was statistically significantly 
higher under aspen (31.18 $\mathrm{Mg} \mathrm{Cha}^{-1}$ ) than under conifer (22.84 $\mathrm{Mg} \mathrm{C}^{-1}$ ), with mixed stands having intermediate values (25.67 $\mathrm{Mg} \mathrm{C}^{-1}$ ) (Table 3). This pattern was not visible along the aspen-conifer gradient in the plots (Figure $3 \mathrm{~b}$ and Table 4), nor was there an obvious LBA threshold. However, there was a positive correlation between MoM C concentration $\left(\mathrm{mg} \mathrm{C} \mathrm{g}^{-1}\right.$ soil) and aspen contribution to LBA (\%) (Figure 3a). The relative distribution of SOC among the different fractions (expressed by the percent of SOC) was similar across the vegetation types in plots and transects, probably due to the high variability in LF content in our sites. These results somewhat contradict previous observations from montane semi-arid [26] and boreal aspen-conifer forests [30], where aspen stands had a significantly higher proportion of SOC in the MoM fraction than mixed and conifer stands.

Figure 3. (a) MoM C concentration ( $\mathrm{mg} \mathrm{C} \mathrm{g}^{-1}$ soil) vs. aspen contribution to LBA (\%). (b) MoM content $\left(\mathrm{Mg} \mathrm{C} \mathrm{ha}^{-1}\right)$ vs. aspen contribution to LBA (\%). $\beta$ represents the slope for aspen LBA (\%) (c) MoM content vs. silt + clay content by dominant overstory in Cedar Mountain plots.
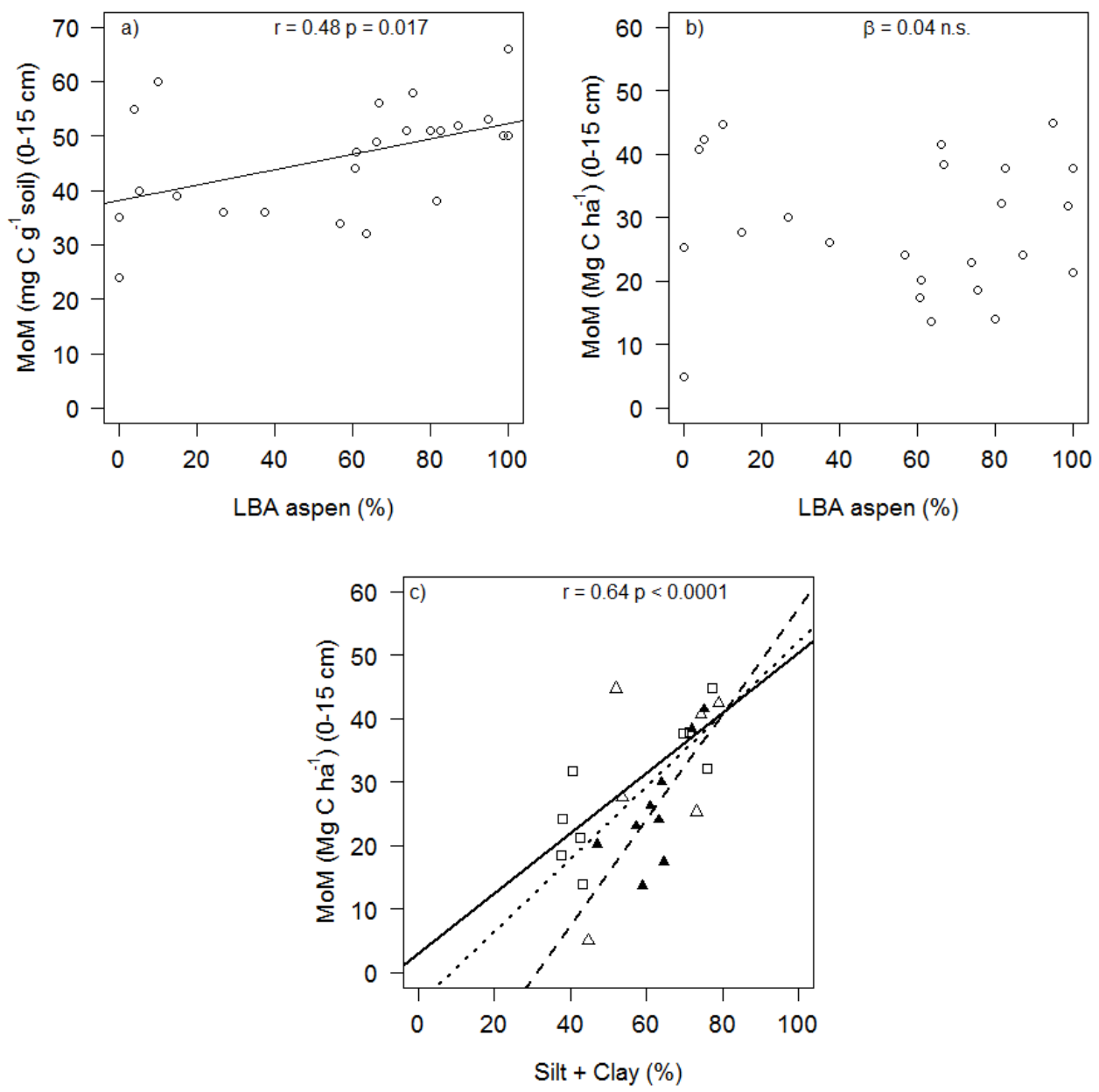

- Aspen - Aspen dominated overstory

- Mixed .... Mixed overstory

$\Delta$ Conifer ..... Conifer dominated overstory 
Table 3. Mean values and standard deviation of the soil properties of transect samples by vegetation class, and the $p$-values from the Type III ANOVA testing the main effects of vegetation and silt + clay content (\%). Different letters indicate statistically significant differences among the means at a 5\% probability level. TOC, total organic carbon; SOC, soil organic carbon; MoM, mineral-associated SOC in the clay and silt fraction; $\mathrm{MA}>53 \mu \mathrm{m}$, mineral-associated $\mathrm{SOC}$ in the sand fraction; $\mathrm{LF}$, light fraction; $\mathrm{Cum}$. $\mathrm{CO}_{2}-\mathrm{C}$, cumulative released $\mathrm{CO}_{2}-\mathrm{C}$ in long term incubations; HWEOC, hot water extractable organic carbon; DOC, dissolved organic carbon; SUVA, specific ultra violet absorbance at $254 \mathrm{~nm} ; \mathrm{P}, \mathrm{P}$ value.

\begin{tabular}{|c|c|c|c|c|c|c|c|c|c|}
\hline & $\begin{array}{c}\text { Bulk } \\
\text { Density } \\
\left(\mathrm{g} \mathrm{cm}^{-3}\right)\end{array}$ & $\begin{array}{c}\text { TOC } \\
\left(\mathrm{mg} \mathrm{C} \mathrm{g}^{-1}\right) \\
(0-5 \mathrm{~cm})\end{array}$ & $\begin{array}{c}\text { TOC } \\
\left(\mathrm{mg} \mathrm{C} \mathrm{g}^{-1}\right) \\
(5-10 \mathrm{~cm})\end{array}$ & $\begin{array}{c}\text { SOC } \\
\left(\mathrm{Mg} \mathrm{C} \mathrm{ha}^{-1}\right) \\
(0-15 \mathrm{~cm})\end{array}$ & $\begin{array}{c}\text { MoM } \\
\left(\mathrm{Mg} \mathrm{C} \mathrm{ha}^{-1}\right) \\
(0-15 \mathrm{~cm})\end{array}$ & $\begin{array}{c}\mathrm{MA}>53 \mu \mathrm{m} \\
\left(\mathrm{Mg} \mathrm{C} \mathrm{ha}{ }^{-1}\right) \\
(0-15 \mathrm{~cm})\end{array}$ & $\begin{array}{c}\mathrm{LF} \\
\left(\mathrm{Mg} \mathrm{C} \mathrm{ha}^{-1}\right) \\
(0-15 \mathrm{~cm})\end{array}$ & $\begin{array}{c}\text { MoM } \\
\text { (\% SOC) }\end{array}$ & $\begin{array}{c}\text { MA }>53 \mu \mathrm{m} \\
(\% \text { SOC })\end{array}$ \\
\hline Aspen & $0.85 \pm 0.15$ & $67.1 \pm 23.4$ & $49.9 \pm 22.0$ & $51.8 \pm 22.6$ & $31.2 \pm 15.1 \mathrm{a}$ & $3.2 \pm 1.9$ & $17.5 \pm 11.5$ & $59.0 \pm 14.7$ & $6.8 \pm 3.6$ \\
\hline Mixed & $0.83 \pm 0.15$ & $69.7 \pm 18.0$ & $49.1 \pm 16.2$ & $47.4 \pm 10.0$ & $25.7 \pm 8.8 \mathrm{ab}$ & $3.2 \pm 1.6$ & $18.5 \pm 5.9$ & $53.5 \pm 11.0$ & $7.5 \pm 3.7$ \\
\hline Conifer & $0.82 \pm 0.13$ & $78.3 \pm 21.8$ & $44.4 \pm 18.1$ & $40.9 \pm 13.3$ & $22.8 \pm 9.0 \mathrm{~b}$ & $3.0 \pm 1.8$ & $15.1 \pm 6.9$ & $55.6 \pm 12.0$ & $6.7 \pm 2.9$ \\
\hline P Vegetation & 0.842 & 0.264 & 0.674 & 0.274 & 0.035 & & 0.544 & 0.200 & \\
\hline \multirow[t]{2}{*}{ P Silt + Clay } & & 0.009 & 0.102 & 0.583 & 0.255 & & 0.718 & 0.050 & \\
\hline & $\begin{array}{c}\text { LF } \\
(\% \mathrm{SOC}) \\
\end{array}$ & $\begin{array}{c}\mathrm{Cum} . \mathrm{CO}_{2}-\mathrm{C} \\
\left(\mathrm{mg} \mathrm{C} \mathrm{g} \mathrm{soil}{ }^{-1}\right)\end{array}$ & $\begin{array}{l}\text { Cum. } \mathrm{CO}_{2}-\mathrm{C} \\
\left(\mathrm{mg} \mathrm{C} \mathrm{g} \mathrm{C}{ }^{-1}\right)\end{array}$ & $\begin{array}{c}\text { HWEOC } \\
\left(\mathrm{mg} \mathrm{DOC} \mathrm{g} \mathrm{soil}{ }^{-1}\right)\end{array}$ & $\begin{array}{c}\text { HWEOC } \\
\left(\mathrm{mg} \mathrm{DOC} \mathrm{g} \mathrm{C}^{-1}\right) \\
\end{array}$ & $\begin{array}{c}\text { SUVA } \\
\left(\mathrm{abs} \times \mathbf{1 0 0 ~ \mathrm { mg } \mathrm { C } ^ { - 1 } )}\right. \\
\end{array}$ & Clay (\%) & Silt (\%) & Sand (\%) \\
\hline Aspen & $34.2 \pm 13.3$ & $5.1 \pm 3.0$ & $86.2 \pm 61.8$ & $0.6 \pm 0.4$ & $9.4 \pm 6.3$ & $2.7 \pm 0.4$ & $23.2 \pm 7.7$ & $35.9 \pm 13.6$ & $40.9 \pm 19.3$ \\
\hline Mixed & $39.9 \pm 11.4$ & $7.4 \pm 5.8$ & $109.3 \pm 87.4$ & $0.6 \pm 0.4$ & $8.9 \pm 4.6$ & $2.7 \pm 0.3$ & $22.6 \pm 10.0$ & $40.0 \pm 14.3$ & $37.6 \pm 20.1$ \\
\hline Conifer & $36.9 \pm 10.5$ & $6.2 \pm 2.0$ & $81.5 \pm 27.3$ & $0.9 \pm 1.1$ & $11.3 \pm 10.6$ & $2.8 \pm 0.8$ & $25.0 \pm 8.7$ & $42.8 \pm 13.5$ & $32.2 \pm 19.7$ \\
\hline P Vegetation & 0.160 & 0.228 & 0.530 & 0.398 & 0.640 & 0.625 & 0.162 & 0.691 & 0.376 \\
\hline P Silt + Clay & 0.190 & 0.209 & 0.045 & 0.364 & 0.120 & 0.488 & & & \\
\hline
\end{tabular}


Table 4. Linear mixed effects model estimates for the intercept, the slope for the contribution of aspen to LBA (\%), the slope for silt + clay (\%) and the variance explained by the site and residuals for different SOC properties from the plot samples.

\begin{tabular}{|c|c|c|c|c|c|c|c|c|c|}
\hline Response Variable & Intercept & $t$-Value & $p$ & Aspen LBA (\%) & $t$-Value & $p$ & Silt + Clay (\%) & $t$-Value & $p$ \\
\hline $\operatorname{SOC}\left(\mathrm{Mg} \mathrm{C} \mathrm{ha}^{-1}\right)$ & $33.06 \pm 20.55$ & 1.61 & 0.143 & $0.07 \pm 0.09$ & 0.79 & 0.438 & $0.17 \pm 0.31$ & 0.55 & 0.598 \\
\hline $\operatorname{MoM}\left(\mathrm{Mg} \mathrm{C} \mathrm{ha}^{-1}\right)$ & $-4.45 \pm 9.36$ & -0.48 & 0.639 & $0.04 \pm 0.05$ & 0.71 & 0.489 & $0.51 \pm 0.14$ & 3.81 & 0.001 \\
\hline $\operatorname{LF}\left(\mathrm{MgC} \mathrm{ha}^{-\mathbf{1}}\right)^{1}$ & $-0.28 \pm 0.08$ & -3.25 & 0.005 & $4.43 \times 10^{-4} \pm 3.18 \times 10^{-4}$ & 1.39 & 0.181 & $-6.18 \times 10^{-4} \pm 1.25 \times 10^{-3}$ & -0.49 & 0.628 \\
\hline MoM (\%) & $28.79 \pm 13.23$ & 2.18 & 0.048 & $3.59 \times 10^{-3} \pm 0.05$ & 0.07 & 0.946 & $0.52 \pm 0.20$ & 2.66 & 0.019 \\
\hline LF $(\%)$ & $43.09 \pm 10.96$ & 3.93 & 0.001 & $-0.01 \pm 0.04$ & -0.31 & 0.757 & $-0.20 \pm 0.16$ & -1.23 & 0.235 \\
\hline Cum. $\mathrm{CO}_{2}-\mathrm{C}\left(\mathrm{mg} \mathrm{C} \text { g soil }^{-1}\right)^{2}$ & $1.24 \pm 0.86$ & 1.44 & 0.177 & $3.32 \times 10^{-3} \pm 2.96 \times 10^{-3}$ & 1.12 & 0.287 & $-3.96 \times 10^{-3} \pm 0.01$ & -0.33 & 0.744 \\
\hline Cum. $\mathrm{CO}_{2}-\mathrm{C}\left(\mathrm{mg} \mathrm{C} \mathrm{g} \mathrm{C}^{-1}\right)^{2}$ & $4.84 \pm 0.78$ & 6.20 & $<0.0001$ & $1.38 \times 10^{-3} \pm 2.53 \times 10^{-3}$ & 0.55 & 0.598 & $-0.01 \pm 0.01$ & -1.08 & 0.301 \\
\hline HWEOC (mg DOC g soil ${ }^{-1}$ ) & $0.52 \pm 0.25$ & 2.14 & 0.048 & $-1.98 \times 10^{-3} \pm 9.14 \times 10^{-4}$ & -2.17 & 0.044 & $1.04 \times 10^{-3} \pm 3.62 \times 10^{-3}$ & 0.29 & 0.778 \\
\hline HWEOC (mg DOC g C ${ }^{-1}$ ) & $16.66 \pm 5.09$ & 3.28 & 0.006 & $-0.06 \pm 0.02$ & -3.13 & 0.006 & $-0.05 \pm 0.08$ & -0.60 & 0.560 \\
\hline SUVA $\left(\operatorname{abs} \times 100 \mathrm{mg} \mathrm{C}^{-1}\right)^{2}$ & $0.78 \pm 0.52$ & 1.50 & 0.161 & $2.48 \times 10^{-4} \pm 2.05 \times 10^{-3}$ & -0.12 & 0.906 & $0.03 \pm 0.01$ & 4.01 & 0.002 \\
\hline Clay (\%) & $22.68 \pm 3.52$ & 6.45 & $<0.001$ & $-0.01 \pm 0.03$ & -0.42 & 0.681 & & & \\
\hline Silt (\%) & $40.57 \pm 4.31$ & 9.41 & $<0.0001$ & $-0.05 \pm 0.03$ & -1.48 & 0.157 & & & \\
\hline Sand $(\%)$ & $36.74 \pm 6.25$ & 5.88 & 0.001 & $0.06 \pm 0.05$ & 1.27 & 0.220 & & & \\
\hline
\end{tabular}

${ }^{1}$ Transformed with the reciprocal root $\left(-1 / x^{0.5}\right) ;{ }^{2}$ transformed with the logarithm in base 10 . 
On the other hand, silt + clay (\%) had a significant positive effect on MoM content in the plots (Figure 3c and Table 4) and on the relative proportion of SOC as MoM in both transects (Table 3) and plots (Table 4), indicative of the formation of organo-mineral associations on silt and clay particles. Individual LME models by dominant overstory in the plots (e.g., aspen (aspen LBA > 75\%), mixed (aspen LBA 25\%-75\%) and conifer (conifer LBA > 75\%)) suggest that at relatively low silt + clay (\%), there is a vegetation effect, with aspen soils storing more MoM than soils in conifer and mixed forests. At higher silt + clay (\%), the effect of vegetation is negligible or the potential for SOC stabilization is driven by soil texture rather than vegetation (Figure $3 \mathrm{c}$ ). Collectively, these results suggest that SOC stabilization in the mineral-associated fraction is favored by the presence of aspen [26]. This greater accumulation of MoM under aspen may be driven either by a higher concentration of organic matter in the mineral-soil solution interface or a higher affinity between aspen-derived organic compounds and clay minerals or both. Our results indicate that whereas total SOC stocks in the upper mineral soil may not be affected by conifer encroachment, the amount of protected (i.e., more persistent) SOC in soils with low and intermediate silt + clay contents may be below the full potential under conifer compared to similar soils under pure aspen.

The amount and relative contribution of LF was highly variable within and among sites in transects and plots (Figure 4) and was not significantly affected by either vegetation cover (LBA) or soil texture (Tables 3 and 4). The variability of LF among sites likely reflected differences in litter input, root growth and decomposition that were not captured by overstory characteristics in this study. This was somewhat unexpected, as LF is considered responsive to changes in overstory species and land use [7]. In their aspen-conifer comparison, Laganiere et al [30] and Woldeselassie et al. [26] had previously found a higher proportion of unprotected SOC under conifer stands than under aspen stands.

Figure 4. (a) Boxplots of LF stocks by sampled sites in Cedar Mountain and Franklin Basin transects; (b) Boxplots of LF stocks by sampled sites in the Cedar Mountain plots. The boxes represent the 25 th and 75 th percentiles. The median is represented by the horizontal black line. The whiskers represent the 10th and 90th percentiles, and the circles correspond to outliers.
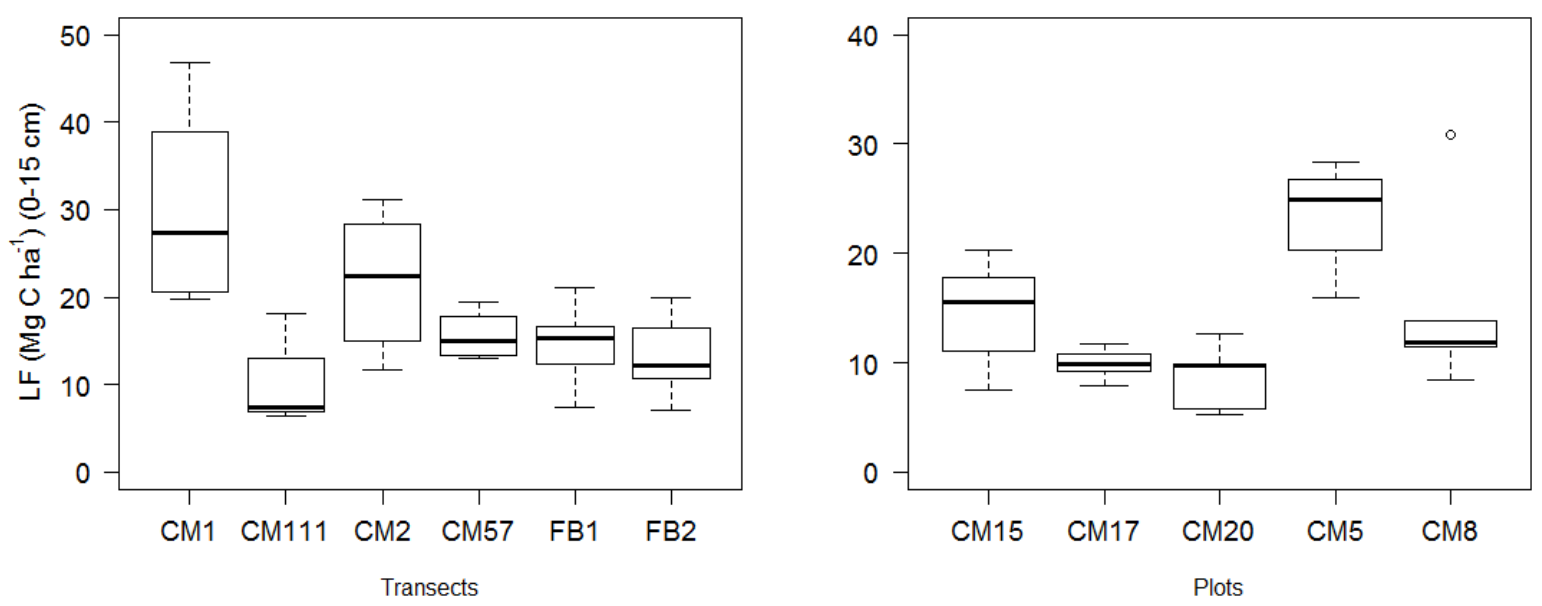

The two methods used to characterize relatively labile SOC, i.e., decomposability (long-term incubations) and solubility (hot water extractions) were positively, albeit weakly, correlated. 
Correlation coefficients were $r=0.34(p=0.024)$ when data were expressed as concentrations on a soil dry weight basis and $r=0.35(p=0.019)$ when expressed per gram of SOC in the soil. This suggests that although the methods are not equivalent, HWEOC can be used as a fast and practical proxy of microbially available SOC when time and/or resources are limited. Our data showed no quantitative or qualitative differences in SOC decomposability with vegetation cover (Table 3) or the relative abundance of aspen in the overstory (Figure 5a and Table 4). Cumulative $\mathrm{CO}_{2}$ release rates ( 5 to $7.5 \mathrm{~g} \mathrm{C} \mathrm{g}^{-1}$ soil) were in a similar range as those reported by Olsen and Van Miegroet [25] for the $0-10 \mathrm{~cm}$ of mineral soil under aspen $\left(3.8 \mathrm{~g} \mathrm{C} \mathrm{g}^{-1}\right.$ soil) and conifer stands $\left(5.1 \mathrm{~g} \mathrm{C} \mathrm{g}^{-1}\right.$ soil). Although in that study, no significant differences in SOC decomposability were found among vegetation classes in surface soils, vegetation had a significant effect at a 10-20-cm soil depth, with conifer soils containing more decomposable SOC than aspen. Similarly, Woldeselassie et al. [26] found that

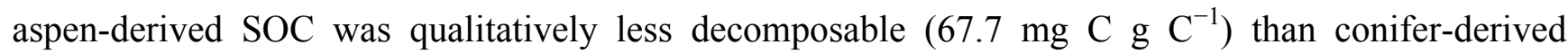

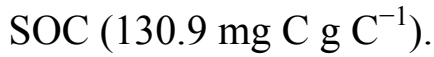

Figure 5. (a) SOC decomposability vs. contribution of aspen to LBA; (b) relative HWEOC concentration $v s$. the contribution of aspen to LBA; (c) SOC decomposability $v s$. silt + clay (\%) or (d) MoM (\% SOC).
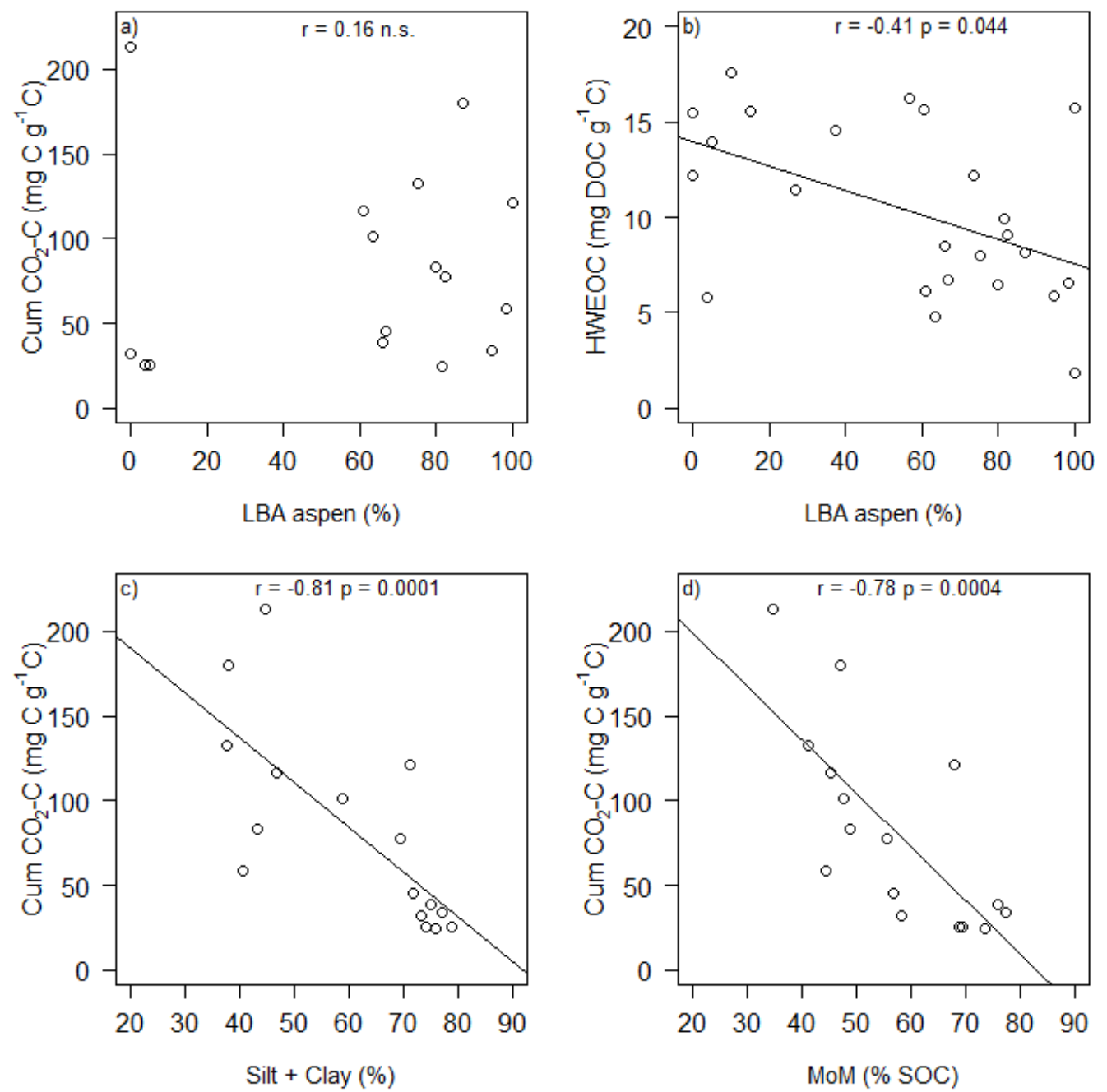
HWEOC concentration, expressed on a soil dry weight basis or per gram of SOC, did not differ among vegetation classes in the transect samples (Table 3). At the plot level, overstory composition had a significant effect on HWEOC concentration per gram of soil $(p=0.044)$ or as a fraction of SOC $(p=0.006)$. The small negative slopes (Table 4) suggest a slight, but statistically significant, decrease in SOC lability with the presence of aspen in the overstory (Figure $5 b$ ).

Variability in cumulative $\mathrm{CO}_{2}$ release per gram of soil was not explained by texture in either transects or plot samples (Tables 3 and 4). Relative silt + clay content had a significant negative effect $(p=0.045)$ on the decomposability of SOC $\left(\mathrm{CO}_{2} \mathrm{~g}^{-1} \mathrm{C}\right)$ in the transects (Table 3), indicated by a negative slope for log-transformed $\mathrm{CO}_{2}-\mathrm{C}$ release $(\beta=-0.016)$. In the plot data, the effect of silt + clay (\%) on decomposable SOC was non-significant when controlling for other factors (Table 4). However, the simple correlation between silt + clay (\%) and SOC decomposability followed the same negative pattern (Figure 5c). The fraction of readily decomposable SOC $\left(\mathrm{mg} \mathrm{C} \mathrm{g}^{-1} \mathrm{C}\right)$ was also negatively correlated with either silt $(\%)(r=-0.47, p=0.001$ transects; $r=-0.51, p=0.044$ plots $)$ or clay (\%) separately ( $r=-0.43, p=0.004$ transects; $r=-0.79, p<0.001$ plots). The percentage of SOC as MoM was further negatively correlated with decomposable SOC per gram of soil $(r=-0.30$, $p=0.047$ transects; $r=-0.70, p=0.002$ plots) or per gram of C (Figure $5 \mathrm{~d}$ ), suggesting that SOC was qualitatively less decomposable as a result of physical-chemical protection.

Silt + clay content (\%) had no effect on HWEOC in transects or plot samples (Tables 3 and 4). However, in transect samples, absolute $\left(\mathrm{mg}\right.$ DOC $\mathrm{g}^{-1}$ soil) and relative HWEOC concentration $\left(\mathrm{mg}\right.$ DOC $\left.\mathrm{g}^{-1} \mathrm{C}\right)$ were negatively correlated with silt + clay content $(r=-0.40, p=0.007$ and $r=-0.59, p<0.0001$, respectively) (Figure 6) and MoM (\% SOC) $(r=-0.81, p<0.0001$ and $r=-0.77, p<0.0001$, respectively). These relationships further support the hypothesis that organo-mineral associations reduce the biological availability of SOC and, therefore, overall SOC stability.

Figure 6. The inverse relationship between silt + clay content (\%) and HWEOC expressed as the fraction of SOC in transect samples.

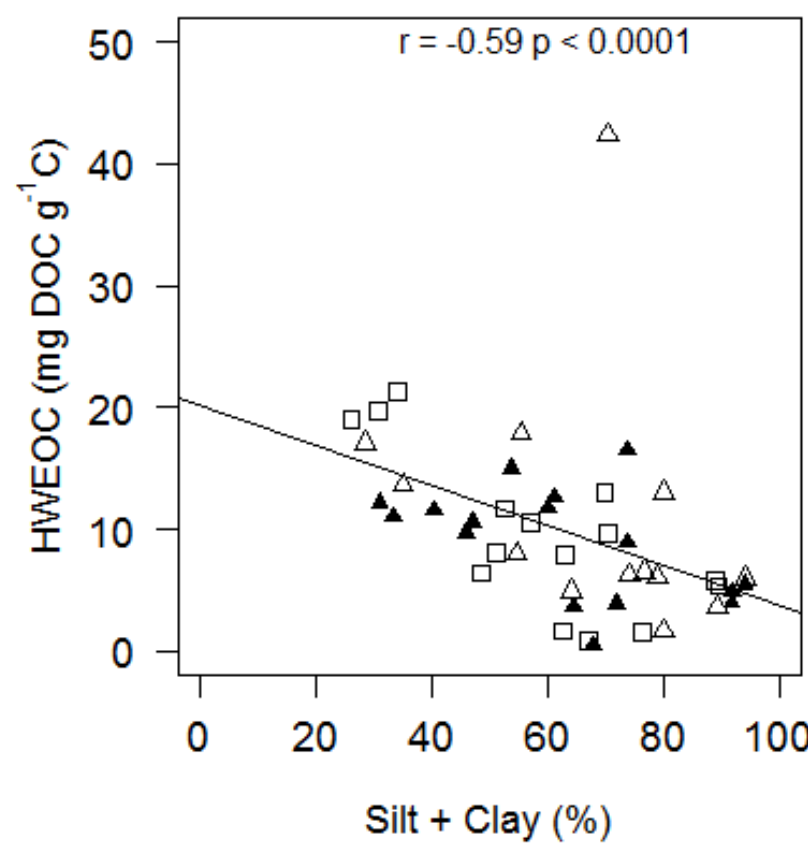


There were significant negative correlations between SUVA and HWEOC concentration ( $\mathrm{g} \mathrm{DOC}^{-1}$ soil) $(r=-0.44, p=0.020)$ in the transects and between SUVA and SOC decomposability $\left(\mathrm{CO}_{2}\right.$ release $\mathrm{g}^{-1}$ soil or $\mathrm{CO}_{2} \mathrm{~g}^{-1} \mathrm{C}$ ) (respectively: $r=-0.69, p=0.005$ and $r=-0.68, p=0.005$ ) in the plots. In other words, higher concentrations of recalcitrant DOC were associated with low bio-availability, as measured during incubation. We interpret these results as an indication that biochemically labile SOC is preferentially used by microbes and depleted from the SOC pool, leaving more recalcitrant SOC to accumulate [51]. Conversely, when labile compounds are more abundant in the soil, the overall concentration of aromatic SOC decreases through relative dilution.

Finally, the negative relationship between total SOC storage and SOC lability expressed as either HWEOC (Figure 7a) and cumulative respired $\mathrm{CO}_{2}-\mathrm{C}$ (Figure 7b) is consistent with Woldeselassie et al. [26], suggesting that the presence of labile SOC in the soil is not conducive to long-term SOC storage. Rather, our results point to the importance of the mineral matrix and especially clay and silt in SOC stabilization and long-term $\mathrm{C}$ sequestration. Organic molecules change their spatial conformation when adsorbed to these mineral surfaces, effectively decreasing SOC decomposition (i.e., $\mathrm{C}$ loss) by limiting the access of organic substrates to microbes or microbial enzymes [52]. Surface interactions between SOC and mineral particles thus results in the longer residence time of the MoM fraction and the accumulation of stable SOC. The relationship between clay content and total SOC storage has been used in regional and global SOC assessments [3,53-55]. In Mediterranean climates, clay content and soil properties contributing to stabilization mechanisms (e.g., polyvalent cations involved in organo-mineral associations) have also been found to favor SOC storage in evergreen oak forests [56].

Figure 7. (a) SOC storage $\left(\mathrm{Mg} \mathrm{C} \mathrm{ha}{ }^{-1}\right)$ vs. relatively soluble $\mathrm{SOC}$ (b) vs. relative decomposable SOC in transects and plots.
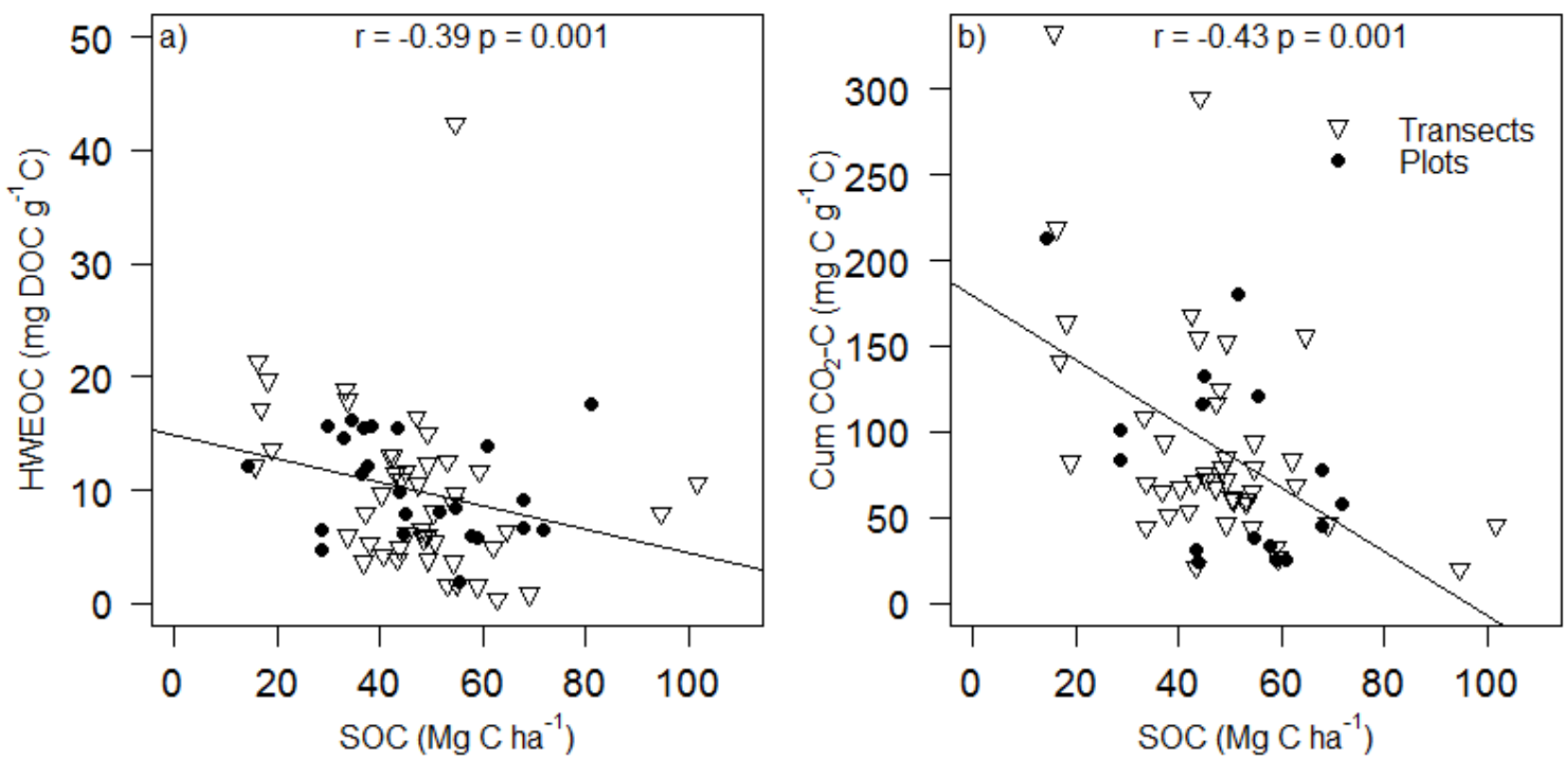

The effect of forest species on total SOC stocks has been investigated in temperate and boreal forests, but without strong evidence or consistent differential SOC storage patterns between conifers 
and hardwoods [57,58]. Even fewer studies in the literature have focused on forest species effects on stable SOC pools. Unprotected SOC pools seem more responsive to changes in overstory composition, but there are not always significant effects of species composition on long-term $\mathrm{C}$ sequestration. Díaz-Pinés et al. [7] found that Scots pine (Pinus sylvestris L.) stored more SOC in unprotected fractions than Pyrenean oak (Quercus pyrenaica Willd.), while mineral-associated SOC content was similar across the pine-oak ecotone. Similarly, Laganière et al. [30] did not find differences in mineral-associated SOC between aspen and black spruce (Picea mariana (Mill.) Britton et al.), but reported more SOC in less protected fractions under black spruce. The content of recalcitrant SOC did not differ significantly between Cunninghamia lanceolata and Michelia macclurei in plantations in subtropical China [59]. In contrast, significantly higher mineral-associated SOC was found under Acacia implexa than under Eucalyptus melliodora [60] in native Australian forests.

While our study clearly supports the role of soil texture in site SOC sequestration potential, we further show that vegetation cover, in this case, the transition from aspen to conifer forests, leads to divergent SOC stabilization. However, the effect of overstory composition on SOC stabilization may be less pronounced in ecosystems where abiotic factors dominate belowground SOC dynamics, such as the presence/absence of mineral adsorption sites. Soils in our study sites were mostly loams, and within that textural class, differences in silt + clay content were a major factor controlling SOC stabilization. At higher clay + silt contents (i.e., $>70 \%$ silt + clay; silty clay to silt loam), the sheer abundance of sorption sites may have compensated for the potential differences in organic matter input and chemistry associated with differences in overstory cover, and vegetation management may prove less effective in creating large differences in belowground SOC storage and stabilization. However, our results suggest that below this range (i.e., $40 \%-70 \%$ silt + clay), vegetation management towards preserving aspen in the landscape may lead to more long-term SOC storage.

Collectively, our results support the importance of MoM in long-term SOC storage, which is favored by the dominance of aspen in the overstory. Woldeselassie et al. [26] proposed that faster turnover of aspen litter, combined with rapid hydrological transport during snowmelt creates a pulse of DOC that enhances C adsorption to mineral surfaces. Slower decomposition of conifer needles, associated with $\mathrm{O}$ horizon accumulation, would conversely result in lower DOC concentrations and, thus, lower adsorption compared to aspen soils. Furthermore, rapid turnover of aspen litter may contribute to SOC stabilization through strong binding of microbial byproducts and dead microbial biomass to mineral surfaces [61]. Several studies have found that microbially-derived compounds are stabilized in the clay fraction [62,63], becoming part of an SOC pool with a long mean residence time. Thus, rapid turnover of litter and a lack of $\mathrm{O}$ horizon accumulation is indeed compatible with SOC stabilization in mineral soil. Conversely, thick $\mathrm{O}$ horizons (as typically observed under conifers) speak to litter recalcitrance, but not necessarily to SOC stability in the mineral soil. We observed some differences in SOC quality with vegetation type, but the few analyses performed in this study are insufficient to draw strong conclusions on the role in SOC stabilization of litter quality differences in aspen vs. conifers, an area that we are currently investigating. While SOC stability depends on the simultaneous action of biochemical recalcitrance and physico-chemical protection, biochemical recalcitrance may play a secondary role in SOC storage [64].

Belowground $\mathrm{C}$ allocation via rhizodeposition and fine root turnover may be another important contributor to the greater SOC stabilization under aspen [65]. Aspen develops a widespread shallow 
lateral root system, from which root suckers originate as a mechanism of asexual regeneration [66]. However, in the Canadian boreal forest, fine root net primary production and the relative contribution to total detritus input were lower for aspen than for jack pine (Pinus banksiana Lamb.) or black spruce (Picea mariana (Mill.) Britton et al.) [67]. Aspen root volume does not decline significantly in the initial stages of conifer encroachment and can contribute to $25 \%-50 \%$ of total fine root biomass in conifer dominated tree clusters [66,68]. Sheppard and Smith [66] reported changes in large root ( $>4 \mathrm{~mm}$ in diameter) volume and non-structural carbohydrate concentrations with stand age in the central Rocky Mountains of Colorado, and more recently, Hudler [69] showed an increase in soluble C compounds in the roots of aspen with increasing aspen LBA in Southern Utah. These root-derived non-structural compounds may constitute another pathway of $\mathrm{C}$ inputs to the soil. The lack of correlation between aboveground and belowground $\mathrm{C}$ allocation patterns may explain why using aspen LBA was not a strong predictor for many SOC properties. Changes in soil microbial community composition and abundance [27], microclimate [25] and hydrology [24] induced by conifer encroachment may further modify the species-specific mechanisms of SOC stabilization in aspen forests.

\section{Conclusions}

While differences in SOC storage across the aspen-conifer gradient were not always clearcut, potentially due to the high variability in abiotic factors (e.g., soil parent material, texture or landscape position), our results nevertheless suggest that aspen stores more SOC in association with silt and clay, increasing the pool of longer residence time SOC. In conifer-dominated stands, on the other hand, SOC is more susceptible to losses through microbial decomposition. This suggests that conifer encroachment may lead to an increase in less-protected SOC, which may turn over faster, depending on environmental conditions (e.g., soil temperature, soil moisture), accelerate decomposition of existing SOC (so-called priming effect) and result in a progressive decline in total SOC storage. Nevertheless, SOC in the mineral-associated fraction may be less affected by conifer encroachment in sites with high silt and clay content. Management strategies pursuing $\mathrm{C}$ sequestration in forest ecosystems should therefore not seek to simply increase SOC content, but rather enlarge SOC pools with a longer residence time, i.e., stabilized through adsorption to the mineral surfaces, as they are less sensitive to disturbances or changes in environmental conditions [64].

The addition of large amounts of more labile SOC forms, at best, contributes to a temporary increase in SOC storage, as they are likely to turn over within a matter of years. Although the geographic scope of our study does not allow us to make broad generalizations for the entire distribution range of aspen in the western US, we observed $25 \%-30 \%$ more mineral-associated SOC in the top soil under aspen compared to adjacent conifer stands. Especially, for finer textured soils conducive to SOC stabilization, management efforts to increase stable SOC pools in the topsoil of montane and subalpine forests should concentrate on the conservation and regeneration of aspen.

\section{Acknowledgments}

This research project was supported by the Utah Agricultural Experiment Station (McIntire-Stennis) and the Cedar Mountain Research Initiative. We thank James Long for his help with the sampling 
design, Susan Durham for her advice with the statistical analysis, and Astrid Jacobson, Xystus Amakor, David Powelson, Marie-Cécile Gruselle, Cody Mittanck, Antra Boča and the many undergraduate students for their help with the field sampling and laboratory analysis.

Publication No. 8640, Utah Agricultural Experiment Station, Utah State University, Logan, UT $84322-4810$.

\section{Author contributions}

Initial concept (Helga Van Miegroet); sample collection, data processing, and statistical analysis (Mercedes Román Dobarco); experimental design, manuscript outline, interpretation of results and writing (Helga Van Miegroet \& Mercedes Román Dobarco).

\section{Conflicts of Interest}

The authors declare no conflict of interest.

\section{References}

1. Dixon, R.K.; Brown, S.; Houghton, R.A.; Solomon, A.M.; Trexler, M.C.; Wisniewski, J. Carbon pools and flux of global forest ecosystems. Science 1994, 263, 185-190.

2. Post, W.M.; Emanuel, W.R.; Zinke, P.J.; Stangenberger, A.G. Soil carbon pools and world life zones. Nature 1982, 298, 156-159.

3. Jobbagy, E.G.; Jackson, R.B. The vertical distribution of soil organic carbon and its relation to climate and vegetation. Ecol. Appl. 2000, 10, 423-436.

4. Barger, N.N.; Archer, S.R.; Campbell, J.L.; Huang, C.Y.; Morton, J.A.; Knapp, A.K. Woody plant proliferation in North American drylands: A synthesis of impacts on ecosystem carbon balance. J. Geophys. Res. 2011, 116, G00K07:1-G00K07:17.

5. Lal, R. Forest soils and carbon sequestration. For. Ecol. Manage. 2005, 220, 242-258.

6. Jandl, R.; Lindner, M.; Vesterdal, L.; Bauwens, B.; Baritz, R.; Hagedorn, F.; Johnson, D.W.; Minkkinen, K.; Byrne, K.A. How strongly can forest management influence soil carbon sequestration? Geoderma 2007, 137, 253-268.

7. Díaz-Pinés, E.; Rubio, A.; van Miegroet, H.; Montes, F.; Benito, M. Does tree species composition control soil organic carbon pools in Mediterranean mountain forests? For. Ecol. Manag. 2011, 262, 1895-1904.

8. Russell, A.E.; Cambardella, C.A.; Ewel, J.J.; Parkin, T.B. Species, rotation, and life-form diversity effects on soil carbon in experimental tropical ecosystems. Ecol. Appl.2004, 14, 47-60.

9. Shutou, K.; Nakane, K. Change in soil carbon cycling for stand development of Japanese cedar (Cryptomeria Japonica) plantations following clear-cutting. Ecol. Res. 2004, 19, 233-244.

10. Vesterdal, L.; Schmidt, I.K.; Callesen, I.; Nilsson, L.O.; Gundersen, P. Carbon and nitrogen in forest floor and mineral soil under six common European tree species. For. Ecol. Manag. 2008, $255,35-48$. 
11. Schmidt, M.W.I.; Torn, M.S.; Abiven, S.; Dittmar, T.; Guggenberger, G.; Janssens, I.A.; Kleber, M.; Kogel-Knabner, I.; Lehmann, J.; Manning, D.A.C.; et al. Persistence of soil organic matter as an ecosystem property. Nature 2011, 478, 49-56.

12. Six, J.; Conant, R.T.; Paul, E.A.; Paustian, K. Stabilization mechanisms of soil organic matter: Implications for C-saturation of soils. Plant Soil 2002, 241, 155-176.

13. Baldock, J.A.; Skjemstad, J.O. Role of the soil matrix and minerals in protecting natural organic materials against biological attack. Org. Geochem. 2000, 31, 697-710.

14. Von Luetzow, M.; Koegel-Knabner, I.; Ekschmitt, K.; Matzner, E.; Guggenberger, G.; Marschner, B.; Flessa, H. Stabilization of organic matter in temperate soils: Mechanisms and their relevance under different soil conditions-A review. Eur. J. Soil Sci. 2006, 57, 426-445.

15. Laganière, J.; Paré, D.; Bergeron, Y.; Chen, H.Y.H.; Brassard, B.W.; Cavard, X. Stability of soil carbon stocks varies with forest composition in the Canadian boreal biome. Ecosystems 2013, 16, 852-865.

16. Peet, R.K. Forests of the Rocky Mountains. In North American Terrestrial Vegetation; Barbour, M.G., Billings, W.D., Eds.; Cambridge University Press: Cambridge, UK, 1988; pp. 63-102.

17. Kurzel, B.P.; Veblen, T.T.; Kulakowski, D. A typology of stand structure and dynamics of Quaking aspen in northwestern Colorado. For. Ecol. Manage. 2007, 252, 176-190.

18. Long, J.N.; Mock, K. Changing perspectives on regeneration ecology and genetic diversity in western quaking aspen: Implications for silviculture. Can. J. For. Res. 2012, 42, 2011-2021.

19. Bartos, D.L.; Campbell, R.B., Jr. Decline of quaking aspen in the interior west-examples from Utah. Rangelands 1998, 20, 17-24.

20. Hessl, A. Aspen, elk, and fire: The effects of human institutions on ecosystem processes. Bioscience 2002, 52, 1011-1022.

21. White, C.A.; Olmsted, C.E.; Kay, C.E. Aspen, elk, and fire in the Rocky Mountain national parks of North America. Wildl. Soc. Bull. 1998, 26, 449-462.

22. Hanna, P.; Kulakowski, D. The influences of climate on aspen dieback. For. Ecol. Manag. 2012, 274, 91-98.

23. Morelli, T.L.; Carr, S.C. A Review of the Potential Effects of Climate Change on Quaking Aspen (Populus tremuloides) in the Western United States and a New Tool for Surveying Sudden Aspen Decline; General Technical Report (PSW-GTR-235); Pacific southwest research station, USDA Forest Service: Albany, CA, USA, 2011.

24. LaMalfa, E.M.; Ryle, R. Differential snowpack accumulation and water dynamics in aspen and conifer communities: Implications for water yield and ecosystem function. Ecosystems 2008, 11, 569-581.

25. Olsen, H.R.; van Miegroet, H. Factors affecting carbon dioxide release from forest and rangeland soils in northern Utah. Soil Sci. Soc. Am. J. 2010, 74, 282-291.

26. Woldeselassie, M.; Van Miegroet, H.; Gruselle, M.C.; Hambly, N. Storage and stability of soil organic carbon in aspen and conifer forest soils of northern Utah. Soil Sci. Soc. Am. J. 2012, 76, 2230-2240. 
27. Ayres, E.; Steltzer, H.; Berg, S.; Wallenstein, M.D.; Simmons, B.L.; Wall, D.H. Tree species traits influence soil physical, chemical, and biological properties in high elevation forests. PLoS ONE 2009, 4, e5964.

28. Stump, L.M.; Binkley, D. Relationships between litter quality and nitrogen availability in Rocky-Mountain forests. Can. J. For. Res. 1993, 23, 492-502.

29. Calder, W.J.; Horn, K.J.; St Clair, S.B. Conifer expansion reduces the competitive ability and herbivore defense of aspen by modifying light environment and soil chemistry. Tree Physiol. 2011, 31, 582-591.

30. Laganière, J.; Angers, D.A.; Pare, D.; Bergeron, Y.; Chen, H.Y.H. Black spruce soils accumulate more uncomplexed organic matter than aspen soils. Soil Sci. Soc. Am. J. 2011, 75, 1125-1132.

31. Rogers, P.C.; Leffler, A.J.; Ryel, R.J. Landscape assessment of a stable aspen community in southern Utah, USA. For. Ecol. Manage 2010, 259, 487-495.

32. Natural Resources Conservation Service. Snow Telemetry (SNOTEL) precipitation and air temperature data for Webster Flat, Kolob, Tony Grove Lake (Utah) and Franklin Basin (Idaho) (1981-2010). Available online: http://www.wcc.nrcs.usda.gov/snow/ (accessed on 8 February 2013).

33. Evans, D.M. A Spatiotemporal Analysis of Aspen Decline in Southern Utah's Cedar Mountain, Using Remote Sensing and Geographic Information Systems. Master's Thesis, Utah State University, Logan, UT, USA, 2010.

34. Tshireletso, K.; Malechek, J.C.; Bartos, D.L. Basal area growth for aspen suckers under simulated browsing on cedar mountain, southern Utah, western United States of America. Botsw. J. Agric. Appl. Sci. 2010, 6, 71-76.

35. McNab, H.W.; Aver, P.E. Ecological Subregions of the United States: Section Descriptions; Administrative Publication, WO-WSA-5; USDA Forest Service: Washington, DC, USA, 1994.

36. Mittank, C.M. Exploring a Stable Aspen Niche within Aspen-Conifer Forests of Utah. Master's Thesis, Utah State University, Logan, UT, USA, 2012.

37. Kusbach, A. Terrestrial Ecosystem Classification in the Rocky Mountains, Northern Utah. Ph.D. Thesis, Utah State University, Logan, UT, USA, 2010.

38. Berger, T.W.; Inselsbacher, E.; Zechmeister-Boltenstern, S. Carbon dioxide emissions of soils under pure and mixed stands of beech and spruce, affected by decomposing foliage litter mixtures. Soil Biol. Biochem. 2010, 42, 986-997.

39. Rhoades, C.C. Single-tree influences on soil properties in agroforestry: Lessons from natural forest and savanna ecosystems. Agrofor. Syst. 1996, 35, 71-94.

40. Gee, G.W.; Bauder, J.W. Particle-Size analysis. In Methods of Soil Analysis. Part 1. Physical and Mineralogical Methods Agronomy Monograph No. 9, 2nd ed.; Klute, A., Ed.; American Society of Agronomy/Soil Science Society of America: Madison, WI, USA, 1986; pp. 383-411.

41. Von Luetzow, M.; Koegel-Knabner, I.; Ekschmitt, K.; Flessa, H.; Guggenberger, G.; Matzner, E.; Marschner, B. SOM fractionation methods: Relevance to functional pools and to stabilization mechanisms. Soil Biol. Biochem. 2007, 39, 2183-2207.

42. Christensen, B.T. Physical fractionation of soil and organic matter in primary particle size and density separates. In Advances in Soil Science; Stewart, B.A., Ed.; Springer New York: New York, NY, USA, 1992; Volume 20, pp. 1-90. 
43. Kaiser, M.; Ellerbrock, R.H.; Sommer, M. Separation of coarse organic particles from bulk surface soil samples by electrostatic attraction. Soil Sci. Soc. Am. J. 2009, 73, 2118-2130.

44. Boutton, T.W.; Archer, S.R.; Midwood, A.J.; Zitzer, S.F.; Bol, R. delta C-13 values of soil organic carbon and their use in documenting vegetation change in a subtropical savanna ecosystem. Geoderma 1998, 82, 5-41.

45. Paul, E.A.; Morris, S.J.; Bohm, S. The determination of soil $\mathrm{C}$ pool sizes and turnover rates: Biophysical fractionation and tracers. In Assessment Methods for Soil Carbon; Lal, R., Kimble, J.M., Follett, R.F., Stewart, B.A., Eds.; Lewis Publishers: Boca Raton, FL, USA, 2001; pp. 193-206.

46. Bu, X.L.; Wang, L.M.; Ma, W.B.; Yu, X.N.; McDowell, W.H.; Ruan, H.H. Spectroscopic characterization of hot-water extractable organic matter from soils under four different vegetation types along an elevation gradient in the Wuyi Mountains. Geoderma 2010, 159, 139-146.

47. Ghani, A.; Dexter, M.; Perrott, K.W. Hot-water extractable carbon in soils: A sensitive measurement for determining impacts of fertilisation, grazing and cultivation. Soil Biol. Biochem. 2003, 35, 1231-1243.

48. Kalbitz, K.; Schmerwitz, J.; Schwesig, D.; Matzner, E. Biodegradation of soil-derived dissolved organic matter as related to its properties. Geoderma 2003, 113, 273-291.

49. Harrell, F.E., Jr.; Dupont, C.; Hmisc: Harrell. Miscellaneous. R package version 3.10-1.1. Available online: http://CRAN.R-project.org/package=Hmisc (accessed on 20 December 2013).

50. Kuznetsova, A.; Brockhoff, P.B.; Christensen, R.H.B. lmerTest: Tests for random and fixed effects for linear mixed effect models (lmer objects of lme4 package). R package version 2.0-0. Available online: http://CRAN.R-project.org/package=lmerTest (accessed on 1 September 2013).

51. Kalbitz, K; Schwesig, D.; Rethemeyer, J.; Matzner, E.; Stabilization of dissolved organic matter by sorption to the mineral soil. Soil Biol. Biochem. 2005, 37, 1319-1331.

52. Baldock, J.A. Interactions of organic materials and microorganisms with minerals in the stabilization of soil structure. In Interactions between Soil Particles and Microorganisms: Impact on the Terrestrial Ecosystem; Huang, P.M., Bollag, J.M., Senesi, N., Eds.; John Wiley \& Sons, Ltd: Chichester, West Sussex, UK, 2002; pp. 85-131.

53. Homann, P.S.; Sollins, P.; Chappell, H.N.; Stangenberger, A.G. Soil organic carbon in mountainous, forested region: Relation to site characteristics. Soil Sci. Soc. Am. J. 1995, 59, $1468-1475$.

54. Amelung, W.; Zech, W.; Zhang, X.; Follett, R.F.; Tiessen, H.; Knoz, E.; Flach, K.W. Carbon, nitrogen and sulfur pools in particle-size fractions as influenced by climate. Soil Sci. Soc. Am. J. 1998, 62, 172-181.

55. Callessen, I.; Liski, J.; Raulund-Rasmussen, K.; Olsson, M.T.; Tau-Strands, L.; Vesterdal, L.; Westman, C.J. Soil carbon stores in Nordic well-drained forest soils-relationships with climate and texture class. Glob. Chang. Biol. 2003, 9, 358-370.

56. Gonzalez, I.G.; Corbi, J.M.G.; Cancio, A.F.; Ballesta, R.J.; Cascon, M.R.G. Soil carbon stocks and soil solution chemistry in Quercus Ilex stands in mainland Spain. Eur. J. For. Res. 2012, 131, $1653-1667$.

57. Vesterdal, L.; Clarke, N.; Sigurdsson, B.D.; Gundersen, P. Do tree species influence soil carbon stocks in temperate and boreal forests? For. Ecol. Manag. 2013, 309, 4-18. 
58. Boča, A.; van Miegroet, H.; Gruselle M.C. Forest overstory effect on soil organic carbon storage: A meta-analysis, proceedings of the North American forests soils conference. Soil Sci. Soc. Am. J. 2014, in press.

59. Wang, Q.K.; Wang, S.L.; Zhong, M.C. Ecosystem carbon storage and soil organic carbon stability in pure and mixed stands of Cunninghamia lanceolata and Michelia macclurei. Plant Soil 2013, 370, 295-304.

60. Kasel, S.; Singh, S.; Sanders, G.J.; Bennett, L.T. Species-specific effects of native trees on soil organic carbon in biodiverse plantings across north-central Victoria, Australia. Geoderma 2011, 161, 95-106.

61. Kleber, M.; Sollins, P.; Sutton, R. A conceptual model of organo-mineral interactions in soils: Self-assembly of organic molecular fragments into zonal structures on mineral surfaces. Biogeochemistry 2007, 85, 9-24.

62. Chotte, J.L.; Ladd, J.N.; Amato, M. Sites of microbial assimilation, and turnover of soluble and particulate ${ }^{14} \mathrm{C}$-labelled substrates decomposing in a clay soil. Soil Biol. Biochem. 1998, 30, 205-218.

63. Rumpel, C.; Kogel-Knabner, I.; Bruhn, F. Vertical distribution, age, and chemical composition of organic, carbon in two forest soils of different pedogenesis. Org. Geochem. 2002, 33, 1131-1142.

64. Rovira, P.; Jorba, M.; Romanya, J. Active and passive organic matter fractions in Mediterranean forest soils. Biol. Fertil. Soils 2010, 46, 355-369.

65. Hancock, J.E.; Loya, W.M.; Giardina, C.P.; Li, L.; Chiang, V.L.; Pregitzer, K.S. Plant growth, biomass partitioning and soil carbon formation in response to altered lignin biosynthesis in Populus tremuloides. New Phytol. 2007, 173, 732-742.

66. Shepperd, W.D.; Smith, F.W. The role of near-surface lateral roots in the life-cycle of aspen in the central Rocky Mountains. For. Ecol. Manag. 1993, 61, 157-170.

67. Steele, S.J.; Gower, S.T.; Vogel, J.G.; Norman, J.M. Root mass, net primary production and turnover in aspen, jack pine and black spruce forests in Saskatchewan and Manitoba, Canada. Tree Physiol. 1997, 17, 577-587.

68. Bauhus, J.; Messier, C. Soil exploitation strategies of fine roots in different tree species of the southern boreal forest of eastern Canada. Can. J. For. Res. 1999, 29, 260-273.

69. Hudler, A. Department of Wildland Resources Utah State University, Logan, UT, USA. Personal Communication, 2014.

(C) 2014 by the authors; licensee MDPI, Basel, Switzerland. This article is an open access article distributed under the terms and conditions of the Creative Commons Attribution license (http://creativecommons.org/licenses/by/3.0/). 